\title{
Phonological awareness tasks: Accuracy in predicting reading and writing difficulties
}

\author{
Cláudia N. G. Justi ${ }^{1}$ \\ iD http://orcid.org/0000-0003-2943-6062 \\ Flávia G. Henriques ${ }^{1}$ \\ iD http://orcid.org/0000-0003-1222-8953 \\ Francis Ricardo dos R. Justi ${ }^{1}$ \\ (iD) http://orcid.org/0000-0001-7107-1672
}

To cite this paper: Justi, C. N. G., Henriques, F. G., \& Justi, F. R. dos R. (2021). Phonological awareness tasks: Accuracy in predicting reading and writing difficulties. Psicologia: Teoria e Prática, 23(3), 1-20. doi:10.5935/1980-6906/ePTPPA13791

Submission: July 31st, 2020.

Acceptance: March 19th, 2021.

1 Federal University of Juiz de Fora (UFJF), Juiz de Fora, MG, Brazil. 


\begin{abstract}
This study evaluated the accuracy of the at-risk/not-at-risk classifications of reading and writing difficulties of different measures of Phonological Awareness (PA). A total of 213 Brazilian children in kindergarten performed six PA tasks (varying in phonological unit and cognitive demand). One year later, 176 of those children performed a writing task and 174 performed a reading task. Receiver Operating Characteristic curves were constructed based on the scores of the reading and writing tasks. The results indicated that the complete set of PA tasks presented the greater area under the curve. However, two PA measures with fewer items, supra-phonemic awareness and phonemic awareness, also presented adequate sensitivity and specificity values for screening purposes. These results are encouraging, since those measures could be used to detect children at risk of reading and writing difficulties in kindergarten (about one year before formal reading and writing instruction in Brazil).
\end{abstract}

Keywords: phonological awareness; phonological processing; screening; reading; writing.

\title{
TAREFAS DE CONSCIÊNCIA FONOLÓGICA: ACURÁCIA EM PREDIZER DIFICULDADES DE LEITURA E ESCRITA
}

\section{Resumo}

Esse estudo avaliou a acurácia de diferentes medidas de Consciência Fonológica (CF) em predizer o risco para dificuldades de leitura e escrita. No último ano da educação infantil, 213 crianças brasileiras foram avaliadas em 6 tarefas de CF. Um ano depois, 174 dessas crianças realizaram uma tarefa de leitura e 176 realizaram uma tarefa de escrita. Curvas de Característica Operacional do Receptor foram construídas com base nos escores de leitura e escrita. O escore total em todas as tarefas de CF apresentou a maior área sob a curva. No entanto, duas medidas de CF compostas por menos itens, consciência supra-fonêmica e consciência fonêmica, apresentaram sensibilidade e especificidade adequadas. Esses resultados são encorajadores já que essas tarefas podem ser utilizadas para rastrear, com um ano de antecedência do ensino formal da leitura e escrita, crianças em risco de desenvolverem dificuldades nessas habilidades.

Palavras-chave: consciência fonológica; processamento fonológico; rastreamento; leitura; escrita. 


\title{
TAREAS DE CONCIENCIA FONOLÓGICA: PRECISIÓN PARA PREDECIR LAS DIFICULTADES DE LECTURA Y ESCRITURA
}

\begin{abstract}
Resumen
Este estudio evaluó la precisión de las clasificaciones de riesgo / no riesgo de dificultades de lectura y escritura de diferentes medidas de conciencia fonológica (CF). Un total de 213 niños brasileños realizaron seis tareas de CF (variando en unidad fonológica y demanda cognitiva) cuando estaban en el jardín de infancia. Un año después, 176 de esos niños realizaron una tarea de escritura y 174 realizaron una tarea de lectura. Las curvas de las Características Operativas del Receptor se construyeron con base en las puntuaciones de las tareas de lectura y escritura. Los resultados indicaron que el total de tareas de CF presentaba la mejor área bajo la curva. Sin embargo, la conciencia supra-fonemas y la conciencia de fonemas, también presentaron valores adecuados de sensibilidad y especificidad. Estos resultados son alentadores ya que esas medidas podrían usarse para detectar a los niños en riesgo de dificultades de lectura y escritura.

Palabras clave: conciencia fonológica; procesamiento fonológico; cribado; lectura; escritura.
\end{abstract}

\section{Introduction}

Identifying children at risk of reading and/or writing difficulties is very important because it allows preventive interventions (Jenkins, Hudson, \& Johnson, 2007). The timing of interventions on reading is essential, as early intervention studies for reading difficulties (for children in kindergarten and $1^{\text {st }}$ grade) present larger effect sizes than later intervention studies (Ozernov-Palchik \& Gaab, 2016). Thus, research about reading and writing development predictors is essential for screening purposes (Jenkins et al., 2007; Ritchey \& Speece, 2004). Among the basic skills related to reading and writing learning, phonological awareness is one of the most important causal factors (Ziegler \& Goswami, 2005). Phonological awareness refers to reflecting on and manipulating speech sounds (Richardson \& Nieminem, 2017). Many studies have demonstrated that performance on tasks evaluating phonological awareness predicts reading and writing development (see, for example, the meta-analysis by Melby-Lervåg, Lyster, \& Hulme, 2012). Children beginning elementary school with difficulties performing phonological awareness tasks are at risk of reading and writing learning difficulties (Ziegler \& Goswami, 2005). Therefore, measures that index this variable are commonly included in 
international test batteries (e.g., DIBELS: Good, Kaminski, Smith, Laimon, \& Dill, 2001) that evaluate the development of key reading and writing learning skills because these data may indicate the appropriate preventive intervention focused on reading and writing.

Although phonological awareness is a strong predictor of reading and writing development (e.g., Melby-Lervåg et al., 2012), it is important to notice that variables that significantly predict the reading and writing development at a general level, as demonstrated by regression analyses, may not accurately predict the reading and writing development at an individual level (Speece, Mills, Ritchey, \& Hillman, 2003). Because efficient prevention of reading and writing difficulties depends on effective measurement to detect, as early as possible, which children are at risk of exhibiting such difficulties and which are not, studies on the classification accuracy of screening measures, such as phonological awareness, are essential.

Jenkins et al. (2007) analyzed several studies on the classification accuracy of various measures used to screen for children at-risk/not-at-risk of reading difficulties. In general, the sensitivity and specificity values associated with different screening measures demonstrate considerable variability. Sensitivity is the probability of the measure to identify individuals at risk of reading difficulties who will in fact have reading difficulties. Specificity is the probability of the measure to identify individuals not at risk of reading difficulties who will have no reading difficulties. Considering the studies conducted with kindergarteners, the sensitivity of different measures ranged from $15 \%$ to $100 \%$, and the lowest sensitivity associated with measures of phonological awareness was $43 \%$ (blending and deletion tasks of the Comprehensive Test of Phonological Processing - CTOPP). Specificity ranged from $56 \%$ to $98 \%$, and the lowest specificity associated with measures of phonological awareness was $78 \%$ (blending and deletion - CTOPP).

To our knowledge, no Brazilian study has investigated the classification accuracy of the phonological awareness measures used to screen for reading and writing difficulties. The study by Andrade, Andrade, and Capellini (2013), conducted with 45 Brazilian children, assessed the sensitivity and specificity of several measures but considered the overall academic achievement (reading, writing, and oral language understanding) as a criterion variable and not reading or writing separately.

In a recent study, Germano, César, and Capellini (2017) evaluated the classification accuracy of phonological awareness in the context of a screening 
protocol for the identification of children at risk of dyslexia. The study included several measures of phonological awareness comprising rhyme production, rhyme identification, syllabic segmentation, production of words from a given phoneme, phonemic synthesis, and phonemic analysis. A total of 149 children, aged from 6 to 6 years and 11 months of age were evaluated in phonological awareness and several other measures when they were in the first grade. An exploratory factor analysis was carried out to reduce the set of variables from the screening protocol, and four factors were retained. The phonological awareness measures were loaded in three different factors: a) one with measures of rhyme, alliteration, and letter-naming knowledge; b) one with measures of phoneme analysis and synthesis, together with measures of rapid automatized naming and word and nonword decoding; and c) one with measures of syllabic segmentation and silent reading. The fourth factor involved sentence comprehension and phonological working memory measures. Children below the $25^{\text {th }}$ percentile in all factor variables were classified as at risk of dyslexia. More children were identified as being at risk for dyslexia by the factor consisting of phoneme analysis, phoneme synthesis, rapid automatized naming, word, and nonword decoding. However, Germano et al. (2017) did not provide ROC curves or sensitivity and specificity values for any factors. In addition, the inclusion of phonological awareness measures in different factors and in conjunction with other variables not theoretically related to phonological awareness makes it difficult to interpret the results concerning the predictive power of phonological awareness alone.

Considering the importance of a screening instrument that allows early identification and preventive intervention in Brazil, studies on the accuracy of screening measures, such as phonological awareness, are essential. Thus, this study investigates the accuracy of the at-risk/not-at-risk classification of reading and writing difficulties of different phonological awareness measures. More specifically, since phonological awareness is supposed to develop from larger phonological units (e.g., words, syllables) to smaller phonological units (e.g., phonemes) (see, e.g., Ziegler \& Goswami, 2005), this study evaluates the accuracy of three phonological awareness measures: phonemic awareness (sum of scores on phonemic tasks); supra-phonemic awareness (sum of scores on supra-phonemic tasks); and total phonological awareness (sum of scores on phonemic and supraphonemic tasks). Another advantage of the present study is that it assessed 
phonological awareness in two periods: when children were in kindergarten and the first grade. Considering that reading and writing skills were assessed when children were in the first grade, the present study evaluates the accuracy of the at-risk/ not-at-risk classification of reading and writing difficulties of different phonological awareness measures both predictively and concurrently to reading and writing instruction.

Regarding the assessment of the classification accuracy of the measures, in addition to reporting the sensitivity and specificity values, the present study reports the area under the curve value, which is an index of the reliability in which two groups, in this case, with reading or writing difficulties, and with no reading or writing difficulties, can be differentiated using the measure. According to Johnson, Jenkins, and Petscher (2010), measures with an area under the curve lower than 0.70 are considered poor, with an area under the curve ranging from 0.70 to 0.79 are considered reasonable, with an area under the curve ranging from 0.80 to 0.89 are considered good and with an area under the curve higher than 0.90 are considered excellent. It is important to notice that these three indices (sensitivity, specificity, and the area under the curve) are properties of the test and, therefore, are not affected by the prevalence of reading/writing difficulties in the sample.

\section{Method}

\subsection{Participants}

This article presents data concerning the second wave of a longitudinal study. The first wave included 213 Brazilian children enrolled in the last year of kindergarten. Of the 213 children, 99 were enrolled in private schools, including 47 boys and 52 girls; and 114 were enrolled in public schools, including 56 boys and 58

girls. Considering the entire sample, the mean age of the children at the beginning of the study was approximately six years old (72.2 months), with a standard deviation of 3.7 months. Of the 213 children who participated in the study at Time 1 (T1) (first wave), 176 performed the writing task ( 88 girls and 88 boys; 97 enrolled in public schools and 79 enrolled in private schools), and 174 performed the reading task (87 girls and 87 boys; 94 enrolled in public schools and 80 enrolled in private schools), both administered Time 2 (T2) (second wave). Nine private schools and 
seven public schools participated in this research study; those schools were from different regions (south, north, east, and center) of a city of approximately 500,000 inhabitants in the state of Minas Gerais, Brazil. Children diagnosed with intellectual disability, including, for example, Down syndrome and fragile $\mathrm{X}$ syndrome, or with sensory impairments such as blindness or deafness were not included in the final sample.

\subsection{Instruments}

\subsubsection{Phonological awareness tasks}

Each phonological awareness task comprised three training items and 10 test items. All words that composed the phonological awareness tasks are commonly used among preschool children (Pinheiro, 1996). For each the tasks, each item answered correctly scored one point. The authors' research group developed the tasks. The phonological awareness tasks in the present study were chosen considering variations in the phonological unit involved (rhymes, syllables, and phonemes) and their cognitive demand (detection of similarities or differences, segmentation, blending, and elision), being representative of the tasks commonly used in other studies to assess phonological awareness (Ziegler \& Goswami, 2005; Richardson \& Nieminem, 2017).

- Rhyme detection task: This task requires the child to say which of three words presented orally and, concomitantly, in figures have a similar final sound, that is, that rhyme. This task presented a Cronbach's alpha reliability coefficient of .55 in the present study.

- Syllable blending task: In this task, each target word is pronounced, including a 1-second pause between each syllable (/Ra/; /to/), and the child is asked to mentally join the syllables and to say the resulting word (/Rato/) (rat in Portuguese). This task presented a Cronbach's alpha reliability coefficient of .92 in the present study.

- Syllable segmentation task: This task requires the child to segment the words spoken by the experimenter (for example: /Rato/) into their respective syllables (/Ra/; /to/), using figures to help the child in this task. This task presented a Cronbach's alpha reliability coefficient of .88 in the present study.

- Phoneme blending task: In this task, isolated phonemes are presented (/R/; $/ \mathrm{a} / ; / \mathrm{t} / ; / \mathrm{o} / \mathrm{l}$, and the child is asked to mentally join them and say the 
resulting word (/Rato/). This task presented a Cronbach's alpha reliability coefficient of .88 in the present study.

- Phoneme segmentation task: This task requires the child to say the phonemes heard (for example: /R/; /a/; /t/;/o/) in the words spoken by the experimenter (for example: /Rato/). Figures are used in this task to visually help the child. This task presented a Cronbach's alpha reliability coefficient of .88 in the present study.

- Phoneme elision task: This task consists of orally presenting a word (for example: /Rato/) and requires the participant to mentally delete a specific sound pronounced by the experimenter (for example: /R/) and say the word with the remaining sound (for example: /ato/). This task presented a Cronbach's alpha reliability coefficient of .87 in the present study.

\subsubsection{Reading and writing tasks}

- Reading Task: Reading Accuracy Task for $1^{\text {st }}$ graders (RAT1). This task, developed by the authors' research group, includes 80 words appropriate for $1^{\text {st }}$ graders (according to Pinheiro, 1996). In this task, all words (balanced for the frequency of occurrence and regularity) were distributed in eight columns containing ten words each. The words were printed in black, in Times New Roman font, size 12, on white paper (A4 size). The child was instructed to read the words on the paper, from left to right and from top to bottom, out loud and as accurately as possible. The score of each child in this task consists of the number of words read out loud correctly. This task presented a Cronbach's alpha reliability coefficient of .98 in the present study.

- Writing Task: Writing Accuracy Task for $1^{\text {st }}$ graders (WAT1). The authors adapted this task based on the Experimental Writing Task (Tarefa Experimental de Escrita) developed by the Laboratory of Studies and Extension on Autism and Development (Laboratório de Estudos e Extensão em Autismo e Desenvolvimento - LEAD) of the Federal University of Minas Gerais for $2^{\text {nd }}$ graders. In this task, the child was asked to write, as accurately as possible, the words dictated by the experimenter. Four groups of words were selected from the preschool word list by Pinheiro (1996), totaling 120 words: Group 1 - regular words; Group 2 - words with contextual rules; Group 3 - words with morphosyntactic rules; and Group 4 - irregular words. The child scores 
one point for each correctly written word. The overall score was used in this task. According to a previous study, this task has a Cronbach's alpha reliability coefficient of .90.

\subsubsection{Data collection procedures}

This study is part of a broader longitudinal study approved by the Human Research Ethics Committee of the institution that the authors are affiliated to. Procedures in this study adhered to ethical research policies and were also approved by the board of the children's schools. In addition to the signing of the Informed Consent Form by the children's guardians, oral assent was obtained from each child at every testing session.

After the schools were contacted and permission to conduct the study in their facilities was granted, all children from the final year of kindergarten who wanted to participate in the study and whose parents authorized their participation performed the phonological awareness tasks described in the previous subsection. The tasks were administered on days and at times agreed upon with the school administrators and teachers. Each child participated in two individual sessions of approximately 30 minutes each. In the first wave (T1), which occurred from November to December, in the children's final year of kindergarten, the phonological awareness tasks described in the previous subsection were administered. In the second wave (T2), conducted between August and September, when the children were in the first year of elementary school, the phonological awareness tasks were administered again, and the reading and writing tasks were administered for the first time. The reading task was administered individually in a single session. The writing task was divided into three sessions, and each session was administered collectively, on a different day.

\section{Results}

Data analysis was performed using the software IBM SPSS Statistics, version 20. To assess the accuracy of the at-risk/not-at-risk classification of reading and writing difficulties of the phonological awareness measures Receiver Operating Characteristic (ROC) curves were constructed based on the scores of the variables "reading difficulty" and "writing difficulty." Data on the maximum possible score of the task, the maximum score obtained, the minimum score obtained, mean, 
standard deviation, skewness, and kurtosis obtained in the phonological awareness, reading, and writing tasks are outlined in Figure 3.1.

Figure 3.1. Descriptive statistics of the phonological awareness, reading, and writing tasks administered.

\begin{tabular}{cccccccc}
\hline & N & Max. T. & Max. O. & Min. O. & M (SD) & Skewness & Kurtosis \\
\hline RhyDet_T1 & 213 & 10 & 10 & 0 & $4.62(2.12)$ & -0.22 & -0.02 \\
\hline SyllBlen_T1 & 213 & 10 & 10 & 0 & $7.68(3.20)$ & -1.39 & 0.66 \\
\hline SyllSeg_T1 & 213 & 10 & 10 & 0 & $6.71(3.18)$ & -0.75 & -0.60 \\
\hline PhonBlen_T1 & 213 & 10 & 10 & 0 & $0.56(1.59)$ & 4.40 & 12.12 \\
\hline PhonSeg_T1 & 212 & 10 & 8 & 0 & $0.26(1.09)$ & 4.92 & 25.20 \\
\hline PhonEli_T1 & 212 & 10 & 10 & 0 & $0.40(1.33)$ & 4.27 & 19.28 \\
\hline RhyDet_T2 & 178 & 10 & 10 & 0 & $5.44(2.28)$ & -0.33 & 0.17 \\
\hline SyllBlen_T2 & 179 & 10 & 10 & 0 & $7.77(3.53)$ & -1.46 & 0.50 \\
\hline SyllSeg_T2 & 179 & 10 & 10 & 0 & $8.16(2.62)$ & -1.72 & 2.06 \\
\hline PhonBlen_T2 & 179 & 10 & 9 & 0 & $1.53(2.51)$ & 1.60 & 1.42 \\
\hline PhonSeg_T2 & 179 & 10 & 10 & 0 & $0.70(1.93)$ & 3.07 & 9.40 \\
\hline PhonEli_T2 & 179 & 10 & 10 & 0 & $1.05(2.27)$ & 2.34 & 4.80 \\
\hline WAT1_T2 & 176 & 120 & 96 & 0 & $29.88(28.49)$ & 0.48 & -1.08 \\
\hline RAT1_T2 & 174 & 80 & 75 & 0 & $29.22(27.15)$ & 0.22 & -1.53 \\
\hline
\end{tabular}

Note: RhyDet = Rhyme Detection; SyllBlen = Syllable Blending; SyllSeg = Syllable Segmentation; PhonBlen = Phoneme Blending; PhonSeg $=$ Phoneme Segmentation; PhonEli $=$ Phoneme Deletion; $\mathrm{T} 1$ = Kindergarten; $\mathrm{T}_{2}=$ First Grade; WAT1 = Writing Accuracy Task/1st grade; RAT1 = Reading Accuracy Task/1st grade; $L N K=$ Letter-Name Knowledge; $N=$ Number of children who performed the task; Max. T. = Maximum Score of the Task; Max. O. = Maximum Score Obtained; Min. O. = Minimum Score Obtained; $M$ = Mean; SD = Standard Deviation.

As expected, it is possible to observe in Figure 3.1 that the scores on the supra-phonemic tasks (rhyme detection, syllable blending, and syllable segmentation) were higher than the scores on the phonemic tasks (phoneme blending, phoneme segmentation, and phoneme elision), both in the kindergarten and in the first grade (paired samples T tests, all p values < 0.01). It is important to notice that children performed above expected level in all tasks, including reading and writing (onesample T tests, all p values < 0.01). Except for the rhyme detection measure, all other 
variables presented very good reliability scores. Thus, the score on the rhyme detection task was excluded from all the following analyses.

Considering the dimensionality and the developmental facets of phonological awareness in previous research (e.g., Justi et al., 2021), three composite measures of phonological awareness were evaluated: supra-phonemic awareness (sum of scores on supra-phonemic tasks: syllable blending and syllable segmentation); phonemic awareness (sum of scores on phonemic tasks: phoneme blending, phoneme segmentation, and phoneme elision); and total phonological awareness (sum of scores on phonemic and supra-phonemic tasks). These measures were calculated to enable the analysis of the accuracy of the at-risk/not-at-risk classification of reading and writing difficulties by the authors of this research.

Reading difficulty was determined as follows: all children with reading accuracy scores one standard deviation below the mean of the sample, equivalent to the 16 th percentile, were classified as having reading difficulty. This criterion was selected because it has been commonly used in other studies (Ritchey \& Speece, 2004). Of the 174 children who performed the reading accuracy task, 64 $(36.8 \%)$ were classified as having reading difficulty, and 110 were classified as having no reading difficulty. Writing difficulty was determined following the same procedure: all children with writing accuracy scores one standard deviation below the mean of the sample were classified as having writing difficulty. Of the 176 children who performed the writing accuracy task, 55 children (31.3\%) were classified as having writing difficulty, and 121 were classified as having no writing difficulty.

To assess the accuracy of the at-risk/not-at-risk classification of reading and writing difficulties of the phonological awareness measures (supra-phonemic awareness, phonemic awareness, and total phonological awareness), receiver operating characteristic (ROC) curves were constructed based on the scores of the variables "reading difficulty" and "writing difficulty." Because the choice to prioritize sensitivity or specificity depends on the objectives of those administering the tasks, we elected to present two cut-off points for each measure: one aiming at the highest possible sensitivity while keeping specificity near .5, and one aiming at the highest possible specificity while keeping sensitivity near .5. The area under the curve values, cut-off points, sensitivity, and specificity of the phonological awareness measures (in kindergarten and first grade) for the variable "reading 
difficulty" are outlined in Figure 3.2, and for the variable "writing difficulty" are outlined in Figure 3.3.

Figure 3.2. Area under the curve, cut-off points, sensitivity, and specificity of the measures of phonological awareness for the variable "reading difficulty."

\begin{tabular}{|c|c|c|c|c|}
\hline \multicolumn{5}{|c|}{ At-risk/Not-at-risk Classification of Reading Difficulty (T2) } \\
\hline Measure & AUC (95\% C.I.) & Cut-off point & Sensitivity & Specificity \\
\hline \multirow{2}{*}{ T1 PA_Total } & \multirow{2}{*}{$.76(.69-.83)$} & $\leq 18$ & .88 & .49 \\
\hline & & $\leq 12$ & .44 & .82 \\
\hline \multirow{2}{*}{ T1 SPhon } & \multirow{2}{*}{$.73(.66-.81)$} & $\leq 16$ & .86 & .60 \\
\hline & & $\leq 11$ & .44 & .77 \\
\hline \multirow{2}{*}{ T1 Phon } & \multirow{2}{*}{$.67(.59-.74)$} & $\leq *$ & $*$ & $*$ \\
\hline & & $\leq *$ & $*$ & $*$ \\
\hline \multirow{2}{*}{ T2 PA_Total } & \multirow{2}{*}{$.81(.74-.87)$} & $\leq 20$ & .95 & .47 \\
\hline & & $\leq 14$ & .53 & .89 \\
\hline \multirow{2}{*}{ T2 SPhon } & \multirow{2}{*}{$.74(.66-.82)$} & $\leq 18$ & .72 & .58 \\
\hline & & $\leq 13$ & .48 & .87 \\
\hline \multirow{2}{*}{ T2 Phon } & \multirow{2}{*}{$.73(.66-.80)$} & $\leq 1$ & .84 & .53 \\
\hline & & $\leq *$ & $*$ & $*$ \\
\hline
\end{tabular}

Note: $\mathrm{T}_{1}=$ kindergarten; $\mathrm{T}_{2}=$ first grade; $\mathrm{AUC}=$ Area under the Curve; $\mathrm{Cl}=$ Confidence Interval; PA_Total $=$ total score in all phonological awareness tasks; SPhon $=$ total score in syllable blending and syllable segmentation tasks; Phon = total score in phoneme blending, phoneme segmentation, and phoneme elision tasks;

* It was not possible to select a cut-off point resulting in a specificity value close to .5 or in a specificity value close to .5 .

As presented in Figure 3.2, considering the phonological awareness measures both in kindergarten and first grade, the measure "PA_Total" presented the highest area under the curve values (.76 in kindergarten and .81 in first grade). Comparing the supra-phonemic and phonemic measures, the first one has a higher area under the curve when measured in kindergarten. However, when measured in the first grade, supra-phonemic and phonemic measures have equivalent AUCs. Interestingly, phonemic awareness measures have a higher area under the curve in first grade compared to kindergarten. On the other hand, the area under the curve of supra- 
phonemic measures in kindergarten is equivalent to the area in the first grade. Overall, except for the phonemic awareness measured in kindergarten ( $A U C=.67$ ), the phonological awareness measures presented appropriate area under the curve values (AUCs > .70).

Considering screening purposes and favoring sensitivity over specificity, it is interesting to notice that "SPhon" in the kindergarten (sensitivity $=.86$ and specificity =.60) and "Phon" in the first grade (sensitivity $=.84$ and specificity = .53) are reasonable substitutes for "PA_Total," especially considering that those measures have fewer items than "PA_Total." However, concerning specificity, it is better to apply the full set of tasks and use the "PA_Total" score.

Figure 3.3. Area under the curve, cut-off points, sensitivity, and specificity of the measures of phonological awareness for the variable "writing difficulty."

\begin{tabular}{|c|c|c|c|c|}
\hline \multicolumn{5}{|c|}{ At-risk/Not-at-risk Classification of Writing Difficulty (T2) } \\
\hline Measure & AUC ( $95 \%$ C.I.) & Cut-off point & Sensitivity & Specificity \\
\hline \multirow{2}{*}{ T1 PA_Total } & \multirow{2}{*}{$.74(.66-.81)$} & $\leq 17$ & .86 & .50 \\
\hline & & $\leq 12$ & .46 & .80 \\
\hline \multirow{2}{*}{ T1 SPhon } & \multirow{2}{*}{$.71(.63-.79)$} & $\leq 16$ & .86 & .55 \\
\hline & & $\leq 11$ & .42 & .82 \\
\hline \multirow{2}{*}{ T1 Phon } & \multirow{2}{*}{$.64(.56-.72)$} & $\leq *$ & $*$ & * \\
\hline & & $\leq *$ & * & * \\
\hline \multirow{2}{*}{ T2 PA_Total } & \multirow{2}{*}{$.79(.72-.85)$} & $\leq 20$ & .98 & .45 \\
\hline & & $\leq 14$ & .54 & .85 \\
\hline \multirow{2}{*}{ T2 SPhon } & \multirow{2}{*}{$.71(.62-.79)$} & $\leq 18$ & .73 & .54 \\
\hline & & $\leq 13$ & .49 & .84 \\
\hline \multirow{2}{*}{ T2 Phon } & \multirow{2}{*}{$.76(.69-.83)$} & $\leq 1$ & .91 & .53 \\
\hline & & $\leq *$ & $*$ & $*$ \\
\hline
\end{tabular}

Note: $\mathrm{T}_{1}=$ kindergarten; $\mathrm{T}_{2}=$ first grade; $\mathrm{AUC}=$ Area under the Curve; $\mathrm{Cl}=$ Confidence Interval; PA_Total = total score in all phonological awareness tasks; SPhon = total score in syllable blending and syllable segmentation tasks; Phon = total score in phoneme blending, phoneme segmentation, and phoneme elision tasks;

* It was not possible to select a cut-off point resulting in a specificity value close to .5 or in a specificity value close to .5 . 
As it can be seen in Figure 3.3, considering the prediction of writing difficulties, overall, except for phonemic awareness measured in kindergarten ( $A U C=.64$ ), the phonological awareness measures also presented appropriate area under the curve values (AUCs > .70). The pattern of the results observed for writing difficulties is about the same as those observed for reading difficulties. The main difference is that, in the first grade, the phonemic awareness measure has a higher area under the curve than the supra-phonemic awareness measure. As expected, the full set of phonological awareness tasks ("PA_Total") presented the highest area under the curve values (.74 in kindergarten and .79 in first grade).

Again, considering screening purposes and favoring sensitivity over specificity, it is interesting to notice that "SPhon" in the kindergarten (sensitivity = .86 and specificity $=.55$ ) and "Phon" in the first grade (sensitivity $=.91$ and specificity $=.53$ ) are good substitutes for "PA_Total," especially considering that those measures have fewer items than "PA_Total." However, concerning specificity, it is better to apply the full set of tasks and to use the "PA_Total" score.

\section{Discussion and Conclusion}

This study sought to evaluate the accuracy of the at-risk/not-at-risk classification of reading and writing difficulties of three phonological awareness measures. Except for phonemic awareness in kindergarten, all phonological awareness measures presented appropriate area under the curve values (> .70). These results are very important for preventive interventions and screening purposes, especially considering that those measures ("T1 PA_Total" and "T1 SPhon") were used to predict reading and writing difficulties one year later. As expected, the area under the curve values increased when the phonological awareness tasks were applied concurrently with reading and writing tasks (in the first grade).

The fact that the area under the curve of the phonemic awareness measure increased from kindergarten to the first grade is in accordance with the reciprocal relationship between phonemic awareness and reading acquisition (e.g., Ziegler \& Goswami, 2005). In addition, the appropriate predictive power of the supraphonemic awareness is also following existing literature, demonstrating that sensitivity to rhymes and syllables at an earlier age is predictive of future reading and writing skills (e.g., Goswami \& Bryant, 1990; Roazzi, Roazzi, Justi, \& Justi, 2013). 
Considering screening purposes and favoring sensitivity over specificity, this study's results suggest that supra-phonemic awareness measures in kindergarten and phonemic awareness measures in the first grade are good substitutes for the full set of phonological awareness tasks employed in the present study. This fact is important because measures having fewer items require less time for its administration and do not cause much frustration among the children with more difficulties, since those children are not exposed to an excessive number of items, thereby contributing to maintaining the child's motivation and attention during the tests. In addition, supra-phonemic awareness in kindergarten and phonemic awareness in the first grade presented sensitivity very close to the standard of .90 while maintaining a specificity of at least .50 (Catts et al., 2009).

It should be noted that, considering the area under the curve, this study's findings regarding the accuracy of the at-risk/not-at-risk classification of reading or writing difficulties do not differ considerably from the findings of other studies that employed phonological awareness measures. For example, Coker and Ritchey (2013) analyzed the writing difficulty established by the teacher and determined that the area under the curve of the phonological awareness measure was 0.76 (90\% sensitivity was associated with a $30 \%$ specificity). In addition, in the study by Clemens, Shapiro, and Thoemmes (2011), the phonological awareness measure, when analyzed separately, had an area under the curve of only 0.68. In turn, Nelson (2008) determined that the sensitivity and the specificity of phonological awareness for the at-risk/not-at-risk classification of writing difficulty, considering a specific cutoff point, were equal to $67 \%$; and when considering another cut-off point, were equal to $94 \%$ and $38 \%$, respectively. Considering the recommendations by Catts et al. (2009) for screening measures (area under the curve higher than 0.90 and sensitivity equal to or greater than .90 and specificity of at least .50), the results of this study are encouraging, especially considering the sensitivity and specificity values of supra-phonemic awareness in kindergarten and phonemic awareness in the first grade.

Considering the growing concern of researchers regarding identifying the most accurate way to classify individuals as at-risk/not-at-risk of reading or writing difficulties, evidence has emerged that a battery comprising measures of different constructs (phonological awareness, letter-name knowledge, and rapid serial naming, among others) has a better classification accuracy than a single 
separate measure (Compton, Fuchs, Fuchs, \& Bryant, 2006). In the study by Clemens et al. (2011), for example, the phonological awareness measure, when analyzed separately, had an area under the curve of 0.68 , which demonstrates that it lacked good accuracy in the at-risk/not at-risk classification of reading difficulties. However, the inclusion of this measure in a battery comprising fluency in word and nonword identification and letter-naming tasks increased the accuracy of the battery (area under the curve $=0.91$ ). The study by Coker and Ritchey (2013) presented similar evidence, although it focused on writing difficulty. In that study, as mentioned, the area under the curve of phonological awareness was 0.76 , but that of the battery as a whole was 0.92 . Thus, future studies must identify which combination of predictors (letter-name knowledge, phonological awareness, rapid serial naming, and phonological working memory, among others) would more accurately detect at-risk and not-at-risk of reading and writing difficulties among Brazilian children. This information does not mean that studies on the accuracy of the at-risk/not-at-risk classification of reading or writing difficulties of individual measures are dispensable. The possibility of identifying a measure that, alone, has good or excellent accuracy for the at-risk/ not-at-risk classification of reading/writing difficulties cannot be discarded. The results from those studies may even indicate which measures should be included in the batteries to be tested. From the prevention science standpoint, such studies are essential.

A limitation of the present study was the lack of a gold standard for diagnosing reading and writing difficulties among Brazilian $1^{\text {st }}$ graders because the reading and writing tests available, including the Teste de Desempenho Escolar [School Achievement Test] (Stein, 1994), were developed for $2^{\text {nd }}$ graders ( $1^{\text {st }}$ graders according to the former system). Considering the lack of those instruments in Brazil that would enable us to conduct the study, measures assessing reading and writing among $1^{\text {st }}$ graders had to be developed. The reading and writing tasks used in the present study were developed based on the study by Pinheiro (1996) because, in that study, the author reported the frequency of the occurrence of words read by kindergarteners (current $1^{\text {st }}$ graders). Therefore, for the reading task, words that were regular, irregular, or that had contextual rules were selected from this list, including half frequent and half infrequent words. For the writing task, words that were regular, irregular, that had contextual and morphosyntactic rules were 
selected, including half frequent and half infrequent words, similar to the task developed by the LEAD for $1^{\text {st }}$ graders (current $2^{\text {nd }}$ graders). Although these measures were experimental, reliability tests (Cronbach's alpha) of the measures used in the present study demonstrated that both have high internal homogeneity ( 0.98 for reading and 0.90 ).

\section{References}

Andrade, O. V., Andrade, P. E., \& Capellini, S. A. (2013). Identificação precoce do risco para transtornos da atenção e da leitura em sala de sula. Psicologia: Teoria e Pesquisa, 29(2), 167-176. doi:10.1590/S0102-37722013000200006

Catts, H., Petscher, Y., Schatschneider, C., Sittner, P., Bridges, M., \& Mendoza, K. (2009). Floor effects associated with universal screening and their impact on the early identification of reading disabilities. Journal of Learning Disabilities, 42(2), 163-176. doi:10.1177/0022219408326219

Clemens, N. H., Shapiro, E. S., \& Thoemmes, F. (2011). Improving the efficacy of first grade reading screening: An investigation of word identification fluency with other early literacy indicators. School Psychology Quarterly, 26(3), 231-244. doi:10.1037/a0025173

Coker, D. L. Jr., \& Ritchey, K. D. (2013). Universal screening for writing risk in kindergarten. Assessment for Effective Intervention, 39(4), 245-256. doi:10.1177/ 1534508413502389

Compton, D. L., Fuchs, D., Fuchs, L. S., \& Bryant, J. D. (2006). Selecting at-risk readers in first grade for early intervention: A two-year longitudinal study of decision rules and procedures. Journal of Educational Psychology, 98(2), 394-409. doi:10.1037/ 0022-0663.98.2.394

Germano, G., César, A., \& Capellini, S. (2017). Screening Protocol for Early Identification of Brazilian Children at Risk for Dyslexia. Frontiers in Psychology, 8, 1763. doi:10.3389/ fpsyg.2017.01763

Good, R. H., Kaminski, R. A., Smith, S., Laimon, D., \& Dill, S. (2001). Dynamic indicators of basic early literacy skills. 5 th ed. Eugene, OR: University of Oregon.

Goswami, U., \& Bryant, P. E. (1990). Phonological skills and learning to read. Hillsdale, NJ: Lawrence Erlbaum. 
Jenkins, J. R., Hudson, R. F., \& Johnson, E. S. (2007). Screening for at-risk readers in a response to intervention framework. School Psychology Review, 36(4), 582-600. do i:10.1080/02796015.2007.12087919

Johnson, E. S., Jenkins, J. R., \& Petscher, Y. (2010). Improving the accuracy of a direct route screening process. Assessment for Effective Intervention, 35(3), 131-140. doi:10.1177/1534508409348375

Justi, C. N. G., Henriques, F. G., \& Justi, F. R. R. (2021). The dimensionality of phonological awareness among Brazilian Portuguese-speaking children: A longitudinal study. Psicologia Reflexão \& Crítica, 34, 26. doi:10.1186/s41155-021-00192-x

Melby-Lervåg, M., Lyster, S.-A. H., \& Hulme, C. (2012). Phonological skills and their role in learning to read: A meta-analytic review. Psychological Bulletin, 138(2), 322-352. doi:10.1037/aoo26744

Nelson, J. M. (2008). Beyond Correlational Analysis of the Dynamic Indicators of Basic Early Literacy Skills (DIBELS): A Classification Validity Study. School Psychology Quarterly, 23(4), 542-552. doi:10.1037/ao013245

Ozernov-Palchik, O., \& Gaab, N. (2016). Tackling the 'dyslexia paradox': Reading brain and behavior for early markers of developmental dyslexia. Wyley Interdisciplynary Reviews: Cognitive Science, 7(2), 156-176. doi:10.1002/wcs.1383

Pinheiro, A. (1996). Contagem de frequência de ocorrência e análise psicolinguística de palavras expostas a crianças na faixa pré-escolar e séries iniciais do $1^{\circ} \mathrm{grau}$. São Paulo: Associação Brasileira de Dislexia.

Richardson, U., \& Nieminen, L. (2017). The contributions and limits of phonological awareness in learning to read. In N. Kucirkova, C. E. Snow, V. Grøver, \& C. McBride (Eds.), The Routledge International Handbook of Early Literacy Education: A Contemporary Guide to Literacy Teaching and Interventions in a Global Context (pp. 264-272). London: Routledge.

Ritchey, K. D., \& Speece, D. L. (2004). Early identification of reading disabilities: Current status and new directions. Assessment for Effective Intervention, 29(13), 13-24. doi:10.1177/073724770402900404

Roazzi, A., Roazzi, M. M., Justi, C. N. G., \& Justi, F. R. R. (2013). A relação entre a habilidade de leitura e a consciência fonológica: Estudo longitudinal em crianças pré-escolares. Estudos e Pesquisas em Psicologia, 13(2), 420-445. Retrieved from http:// www.revispsi.uerj.br/v13n2/artigos/html/v13n2a03.html 
Speece, D. L., Mills, C., Ritchey, K. D., \& Hillman, E. (2003). Initial evidence that letter fluency tasks are valid indicators of early reading skill. Journal of Special Education, 36(4), 223-233. doi:10.1177/002246690303600403

Stein, L. (1994). TDE: Teste de Desempenho Escolar: Manual para aplicação e interpretação. São Paulo: Casa do Psicólogo.

Ziegler, J. C., \& Goswami, U. (2005). Reading acquisition, developmental dyslexia, and skilled reading across languages: A psycholinguistic grain size theory. Psychological Bulletin, 131(1), 3-29. doi:10.1037/0033-2909.131.1.3

\section{Authors' note}

Cláudia N. G. Justi, Cognition and Language Laboratory, Department of Psychology, Federal University of Juiz de Fora (UFJF); Flávia G. Henriques, Cognition and Language Laboratory, Department of Psychology, Federal University of Juiz de Fora (UFJF); Francis

Ricardo dos R. Justi, Cognition and Language Laboratory, Department of Psychology, Federal University of Juiz de Fora (UFJF).

Funding: Cláudia Nascimento Guaraldo Justi received a grant from the National Council for Scientific and Technological Development (CNPq) for conducting this research [grant number 445179/2014-7]. Flávia Guimarães Henriques received a scholarship from the Coordination for the Improvement of Higher Education Personnel (Coordenação de Aperfeiçoamento de Pessoal de Nível Superior - CAPES), Brazil, Finance Code 001.

Correspondence concerning this article should be addressed to Cláudia Nascimento Guaraldo Justi, Department of Psychology, Federal University of Juiz de Fora, Juiz de Fora, MG, Brazil. CEP 36036-330.

E-mail: claudia.ngjusti@gmail.com 
EDITORIAL BOARD

\section{Editor-in-chief}

Cristiane Silvestre de Paula

\section{Associated editors}

Alessandra Gotuzo Seabra

Ana Alexandra Caldas Osório

Luiz Renato Rodrigues Carreiro

Maria Cristina Triguero Veloz Teixeira

\section{Section editors}

Psychological Evaluation

Alexandre Serpa

Luiz Renato Rodrigues Carreiro

Vera Lúcia Esteves Mateus

\section{Psychology and Education}

Alessandra Gotuzo Seabra

Carlo Schmidt

Regina Basso Zanon

\section{Social Psychology}

Enzo Banti Bissoli

\section{Clinical Psychology}

Carolina Andrea Ziebold Jorquera Julia Garcia Durand

Natalia Becker

\section{Human Development}

Maria Cristina Triguero Veloz Teixeira Rosane Lowenthal

\section{Technical support}

Maria Fernanda Liuti Bento da Silva Camila Fragoso Ribeiro

\section{EDITORIAL PRODUCTION}

Publishing coordination

Ana Claudia de Mauro

\section{Editorial interns}

Júlia Lins Reis

Élcio Carvalho

Language editor

Daniel Leão

Layout designer

Acqua Estúdio Gráfico 